\title{
Social representations of sex and gender among trans people
}

\author{
Representações sociais do sexo e gênero entre pessoas trans \\ Representaciones sociales del sexo y género entre personas trans
}

Jaime Alonso Caravaca-Morera', Maria Itayra Padilha'

'Universidade Federal de Santa Catarina, Postgraduate Program in Nursing. Florianópolis, Santa Catarina, Brazil.

How to cite this article:

Caravaca-Morera JA, Padilha MI. Social representations of sex and gender among trans people.

Rev Bras Enferm [Internet]. 2017;70(6):1235-43. DOI: http://dx.doi.org/10.1590/0034-7167-2016-0581

Submission: 11-01-2016 Approval: 02-08-2017

\section{ABSTRACT}

Objective: To analyze the social representations of sex and gender among transsexual people, through their life histories. Method: Qualitative, multicenter and descriptive research. The participants were 70 transsexuals from Brazil and Costa Rica. Data were analyzed according to the technique of Content Analysis. Results: Two complementary representations related to sex were identified: "Sex as a natural categorical imposition sealed and acquired (irremediably) at birth" and "Sex as an element that labels, condemns and differentiates people." Regarding gender, a single representation was associated with "synthetic-social constructions associated with (necro/bio) power, cisnormativity and culture." Final considerations: The former absolute division of gender as social construction and of sex as considered as natural must be questioned in order to analyze both concepts as an interconnected dyad. In addition, it should be recognized that this dyad presents itself as an organizational and cognitive construct, mediated by the still prevalent cispatriarchal (necro/bio) power.

Descriptors: Nursing; Transsexuality; Gender Identity; Social representations; Gender; Sex.

\section{RESUMO}

Objetivo: Analisar as representações sociais de sexo e gênero entre pessoas transexuais, por meio de suas histórias de vida. Método: Pesquisa qualitativa, multicêntrica e descritiva. Participaram 70 transexuais do Brasil e da Costa Rica. Os dados foram analisados segundo a técnica de Análise de Conteúdo. Resultados: identificadas duas representações complementares relacionadas ao sexo: "O sexo como imposição categórica natural lacrada e adquirida (irremediavelmente) ao nascer" e; "O sexo como elemento que rotula, condena e diferencia as pessoas". Com relação ao gênero, observou-se uma única representação vinculada a "elaborações sintético-sociais associadas ao (necro/bio) poder, à cisnormatividade e à cultura". Considerações finais: A antiga divisão absoluta do gênero como construção social e do sexo como dado natural deve ser questionada, a fim de analisar ambos os conceitos como uma díade interconexa. Adicionalmente, deve-se reconhecer que esta díade se apresenta como uma construção organizativa e cognitiva, mediada pelo ainda prevalente (necro/bio) poder cispatriarcal.

Descritores: Enfermagem; Transexualidade; Identidade de Gênero; Representações sociais; Gênero; Sexo.

\section{RESUMEN}

Objetivo: Analizar las representaciones sociales del sexo y género entre personas transexuales, a través de sus historias de vida. Método: Investigación cualitativa, multicéntrica y descriptiva. Participaron 70 personas transexuales de Brasil y Costa Rica. Los datos fueron analizados según la técnica de Análisis de Contenido. Resultados: fueron identificadas dos representaciones complementarias relacionadas al sexo: "El sexo como imposición categórica natural sellada y adquirida (irremediablemente) al nacer" y; "El sexo como elemento que rotula, condena y diferencia a las personas". Con respecto al género, se observó una única representación vinculada a "elaboraciones sintético-sociales asociadas al (necro/bio) poder, a la cisnormatividad y a la cultura". Consideraciones finales: La antigua división del género como construcción social y del sexo como dato natural debe ser cuestionada, a fin de analizar ambos conceptos como una díada interconexa. Además, se debe reconocer que esta díada se presenta como una construcción organizativa y cognitiva, mediada por el todavía prevalente (necro/bio) poder cispatriarcal. Descriptores: Enfermería; Transexualidad; Identidad de género; Representaciones sociales; Género; Sexo. 


\section{INTRODUCTION}

The device of transsexuality is a modern construction, which allows to question the cisheteronormativity - a concept that refers to a set of power relations that normalizes, regulates, idealizes and institutionalizes gender, sex and sexuality in an illogical and strictly horizontal line $\mathrm{e}^{(1)}$ - and identifies some individuals who present specificities under various social, political, and moral discursive frameworks.

Indeed, discussing transsexuality involves reflecting on the real meaning of the institutions "sex" and "gender" beyond the biological/inborn and plastic-cultural conceptions. It implies thinking about everyday experiences in the private and public spheres and the diverse and polysemous sociopolitical boundaries involved.

Furthermore, considering that the linguistic figures of man and woman have existed in all known cultural expressions, it is important to highlight that this interest in deeply researching the radiography of the sexes in the medical academy (by anatomy, biology, and the psychological sciences) originated in the west at the end of the sixteenth century, a period marked by the forced hiding of sexuality thinking ${ }^{(2)}$.

Authors such as Laqueur argue that the opposition of the sexes is a conception from the Enlightenment, for in ancient times the bodies of man and woman were understood as part of a single structure, with the mere modification of their genitals (isomorphism) ${ }^{(3)}$. In other words, both genitalia were seen as analogous nuclei, that is, the fundamental difference was that women had the organs "inverted," in such a way they had the possibility to host a new being(3-4).

However, in opposition to this thought, after the seventeenth century, bodies were no longer conceived as belonging to a single structure and began to "uncover" (seemingly irreconcilable) differences between each other (dimorphism). Thus, this new (artificially conceived) paradigm was clearly capable of transforming sex into a parameter of obligatory social differentiation and, consequently, ascribed to the genitalia the capacity to establish (and justify) power relations and (consequent) submission ${ }^{(5)}$.

In this respect, we located the conception that, through sex (and its derivative differentiation with gender), control and mastery of individualities could be exercised by restricting and punishing cognitive and behavioral possibilities.

From the angle of the techno-artificial concepts created on the basis of biological structures and mediated by (necro/bio) power, the term "gender" was drawn at the discursive aurora, and as with any body of ideas, it did not arise in the intellectual horizon by spontaneous generation. Several currents of thought converged in this process to bring elements together: ideologists of the Sexual Revolution (Wilhelm Reich and Herbert Marcuse), social constructivists (Jacques Derrida and Michel Foucault), existentialists (Simone de Beauvoir), feminists (Shulamith Firestone, Germaine Greer, Joan Scott), among others advocates of the scientific origin of the term "gender" (John Money) ${ }^{(6)}$.

In primitive logic, gender seems to have introduced the distinction concerning culture, according to which it could be conceived as a category based on sociocultural definitions related to the ways in which different social actors should be, think and act in the social spheres they occupy.
In this same line of reasoning, gender appeared as a critically constructed concept on the sexual roles, that is, as a category of prescriptive relation composed of multiple elements with different meanings, although they all have in common the fact of referring to the specificity of traits and psychosocial characteristics linked to the sexual dichotomy/binarity.

Given the timely scenario previously described, the purpose of this manuscript is to analyze the social representations of sex and gender among Brazilian and Costa Rican transsexual subjects, through their life histories. In addition, notwithstanding this academic purpose, we try to open space to give voice to those who are submitted to the rule of (cis)normative law, while at the same time we seek to create strategies of selfaffirmation and reinvention of concepts related to sex, body, gender and sexuality of the participants of this study.

Finally, it is important to emphasize that we use the pronouns he/she with much regret in this research, since these are binary terms that make other sex-gender identifications invisible. However, linguistically, we still do not have other alternatives that allow designating someone without alluding to a sexual and generic binarism.

\section{METHOD}

\section{Ethical aspects}

The observance of ethical principles in this research had fundamental importance in respecting the participants' desires. The project was submitted to an evaluation by the Ethics Committee of Research with Human Beings (CEP) of the Federal University of Santa Catarina (UFSC), according to what was recommended in Ordinance no. 466/2012 of the National Health Council, which regulates guidelines and standards of human research in its various aspects.

After explanations, clarifications and acceptance by the participants, they were asked to sign the Informed Consent Form translated in both languages. To ensure anonymity, the interviews were identified by the terms transman and transwoman, followed by an Arabic number (from 1 to 35), corresponding to the order of interviews, country of origin and year of interview.

\section{Theoretical-methodological reference}

The Theory of Social Representations (SR) was used as theoretical reference. This theory (or theoretical paradigm) is relevant in research linked to the relationships and interactions that people establish with their environment. Social representation was understood as the form of popular knowledge and common sense that is socially developed and shared and which contributes to the construction of a specific reality to a particular group.

It is worth mentioning that social representations are closely interconnected with social practices and cognitions, since they are not only the concrete attributes of a given object or reality that define individual or group conduct, but most of all, the representation that people have of such objects or situations ${ }^{(7)}$.

\section{Type of study}

This is a qualitative, sociohistorical research linked to the thesis Histórias de vida e representações sociais do sexo, corpo, gênero 
e sexualidade entre pessoas transexuais do Brasil, Canadá e Costa Rica (Life histories and social representations of sex, body, gender and sexuality among transsexual people in Brazil, Canada and Costa Rica), which used complete Life Histories as a procedural technique for data collection during the years 2014 and 2015.

\section{Methodological procedures}

The semi-structured interview script used was developed after specific readings on the theme and two pilot interviews conducted in each of the countries (Brazil and Costa Rica), in order to evaluate the semantic and linguistic meaning of the questions contained therein.

The instrument contained, in addition to open questions, a section related to the free-drawing technique at the end of the interview. This technique consisted of asking the participant to draw with colored markers what came to mind immediately after hearing an inductive stimulus, in order to identify the very objectification of SR, through the inductive stimuli "sex" and "gender." These drawings were considered for performing a confirmatory analysis of the elements that composed the central nucleus and peripheral elements of SR.

\section{Study scenario}

Two nongovernmental organizations collaborated with us in this study: Associação em Defesa dos Direitos Humanos com Enfoque na Sexualidade (Association for the Defense of Human Rights with a Focus on Sexuality - ADEH), located in Florianópolis, capital of the state of Santa Catarina, Brazil, and Asociación de Apoyo a la Población Trans (TRANSvida), located in the province of San José, capital of Costa Rica.

Participants were selected through the snowball technique, in which the initial participants linked to the aforementioned institutions indicated potential new collaborators (peers) who could contribute to the goal of this study, forming a network of indications.

In the case of Brazil, the studied population was restricted to subjects residing in the three southern states and receiving some type of support from ADEH. For Costa Rica, individuals from the seven states of the nation were included in the sample, because it was difficult to locate people interested in participating in the study who resided exclusively in San José, because of fear of daytime exposure and because most of the transwomen performed sex-service activities at night (prostitution), which made it difficult to conduct interviews during the day or in the afternoon.

\section{Data source}

The sample consisted of 70 transsexual people from both countries, of whom 35 were Brazilian and 35 were Costa Rican. Of these, 60 were transwomen (people identified at birth as belonging to the male "gender" and who identify with the female gender) and 10 transmen (persons identified at birth as belonging to female "gender" and who identify with male gender). The choice was made intentionally, so as to include participants from two poles of the American continent (Central and South Americas), with two languages characteristic of the region (Spanish and Portuguese).

In this research we understand as trans people those who believe that there is no linear correspondence between their biological (and artificially imposed) sex and their gender identity, and that, at times, this thinking can motivate them to modify their body through hormonal therapy and/or surgical procedure or for eventual change of the social name/pronoun in their legal documents.

Inclusion criteria were: participants aged over 18 years, with legal citizenship of both countries, who considered themselves transsexual (either transwomen or transmen) at the beginning, middle or end of the transition process, or who did not wish to make any physical changes but claimed change of social name and pronoun, excluding only intersexual people (those with conditions of genital ambiguity according to anatomical, histological and/or cytological criteria).

\section{Collection and organization of data}

The date and place for the interviews was chosen by the participants. With their permission, the statements were recorded and later transcribed/transcreated for content analysis. In addition, three focus groups were conducted with some participants in order to assess/verify if the preliminary analyses of the information were being properly conducted by the main investigator and with the purpose of corroborating cultural and semantic expressions possibly not fully understood during some interviews.

\section{Data analysis}

When we turn our attention to the SR of sex and gender of trans people, we follow the rigor required by the use of Serge Moscovici's theoretical reference on the capture aspects of structure, contents, lexical worlds, contextual units, themata, central nucleus, and peripheral elements of each representation to later reflect, verify and understand, according to Bardin's Content Anal$y \mathrm{yis}^{(8)}$, what was presented by the participants.

In addition, by using a pragmatic approach based on the postulates of Moscovici and Vignaux ${ }^{(7)}$ and on Content Analy$\operatorname{sis}^{(7)}$, we determined the elements that made up the SR identified in this research.

Thus, once an attitude from common sense was detected in the participants' statements, we obtained what could later be considered - in a continuous and flexible manner - the social representation.

On the other hand, to analyze the participants' free associations, these were summarized in a matrix divided into topics according to the main meanings expressed in their drawings. Thus, each interviewee was assigned a code (transman or transwoman), followed by the country of origin and an Arabic number (BR: 1-35 + CR: $1-35-\mathrm{N}=70$ ), in such a way that each interview could be associated with a respondent during the analytical process.

Finally, after analysis, two complementary sex-related representations were identified: "Sex as a natural categorical imposition sealed and acquired (irremediably) at birth" and "Sex as an element that labels, condemns and differentiates people." Regarding gender, a single representation was associated with "synthetic-social developments associated with (necro/ bio) power, cisnormativity and culture."

\section{RESULTS}

Introducing ourselves in the debate about SR and based on the set of results from the prototypical analysis, it was possible 
to outline a representational field and to point out, with reasonable probability of correctness, the central and peripheral elements of SR as well as to interpret its organization.

As we begin to approach this semantic analysis to characterize the representation of sex, we find elements associated with the concepts: biology, biological differentiation between people, natural imposition, birth, handcuffs, conviction, penis, vagina and private domain.

After analysis of descending hierarchical classification of the textual data from the interviews, we came across two distinct but complementary sex-related representations. The first refers to sex as a natural categorical imposition sealed and acquired (irremediably) at birth, as expressed in some drawings:

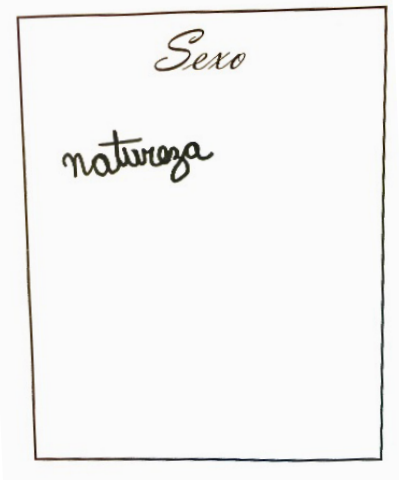

Note: Sexo - Sex; Natureza - Nature Source: Transwoman 12, Brazil, 2014.

Figure 1 - Free drawing technique: sex associated with the word "biology".

Similarly, some statements emerged from the content analysis of the interviews and explain this representation as a natural imposition with elements linked to the words "birth," "imposition," "penis" and "vagina."

\section{Sex as natural imposition}

I wanted to fight because this was imposed to me since I was born, I've always been a woman, but unfortunately testicles and penis came with me with the "birth gift," then I started searching on the Internet how could I produce testosterone, because I was sick and then I decided to do the craziest thing I've ever done, I bought a scalpel, tuberculin syringes and lidocaine on the drug store and started acting like a doctor, and one day, I decided to cut my testicles to remove them, but thank God when it started bleeding and it wouldn't stop, I called a friend to help me [...] I thought I was going to die, I've seen the light. (Transwoman 15, Costa Rica, 2015)

\section{Sex associated with the words "penis" and "vagina"}

I could tell that I did not have what a girl had, that we were different, and that because of that little dick I could not be the woman I always believed to be [...] because of that insignificant little thing I could not be accepted by my father or my family. (Transwoman 26, Brazil, 2014)
The second representation describes sex/genitalia as an element that labels, condemns, and differentiates people to make them (im)productive before society.

\section{Sex associated with the words "handcuffs" and "conviction"}

What does the penis mean in my body? For me, unfortunately, it is a "death sentence," it is a curse that is part of my body, for me it is a damn organ (Transwoman 23, Brazil, 2014)

I think that now, on second thought... everything that means penis and vagina is damnation. Why can penis and vagina have the same meaning? Why can we not live in a world where there is no such rules and you can choose to live as and be whoever you wanna be without being condemned to live with Satan (referring to the penis)? (Transman 6, Costa Rica, 2015)

This (referring to the vagina) means a handcuff (silence), it does not let you be who you are. At first, I felt like this person that others saw, like a person with three eyes, but it was not an eye in excess, it was a vagina [...]. (Transman 5, Brazil, 2014)

And nowadays I'm not happy, I'm condemned to be like this [...] I've never felt like a man, I've always been a grown up woman, but my greatest curse was being born with that thing between my legs. (Transwoman 30, Costa Rica, 2015)

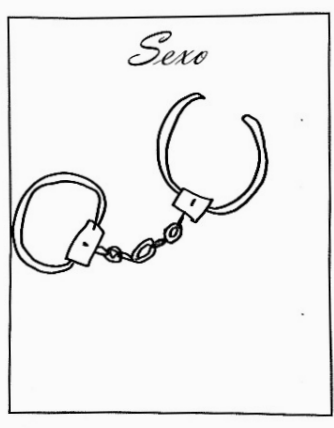

Note: Sexo - Sex

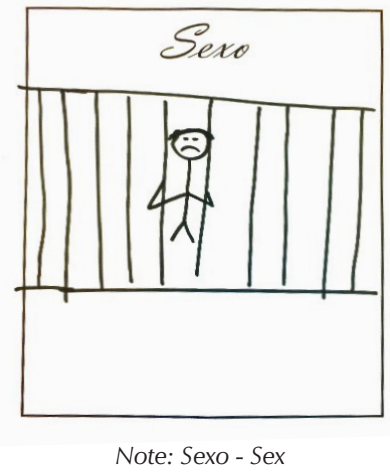

Source: Transwoman 17, Brazil, 2014. Source: Transman 8, Costa Rica, 2015.

Figure 2 - Free drawing technique: sex associated with the words "handcuffs" and "conviction"

Under the logic of the first social representation for this concept, the probable central nucleus contains the words "biology" and "birth" and, in the second, "conviction." Successively, in the sex/gender interrelationship, sex seems to be a variable that, although currently capable of being manipulated clinically to the point of trans/forming it to the contrary, has deep roots in the biological-genetic structure and delimits the terrain of the real where the subject (self)discovers individually.

In addition, we observed that the social representations of this concept were based on the genital aspects and experiences of bathing or privacy during childhood and preadolescence, moments in which the participants questioned the reasons for being born with such biological structures or (some of them) dreamed of having the opposite phenotypic structure. 
On the other hand, regarding the interpretative analysis of gender representation, there emerged elements linked to the concepts of social categories, normative codes, behavioral codes, power, "boxes" and labels, synthetic products, "must be," ideals and expectations, culture, domination.

Regarding the notion of gender representation, we observed only one class, thus, a single representation, linked to syntheticsocial developments associated with cisheteronormativity and culture. We identified a central semantic axis geared to domination, regulation, behavioral and cultural codes, ways of acting, toys/games, with multiple negative aspects voiced through the words discrimination, not fitting, rejection, subordination and aberration, as evidenced in some drawings and statements.

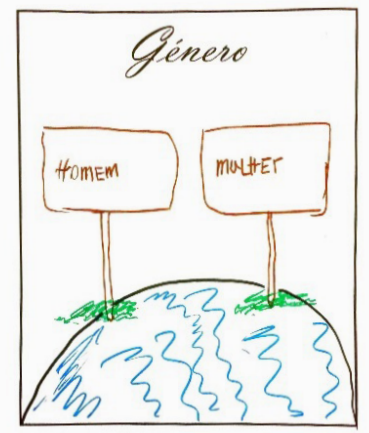

Note: Gênero - Gender;

Source: Transwoman 9, Brazil, 2014.
Man - Homem; Mulher - Woman

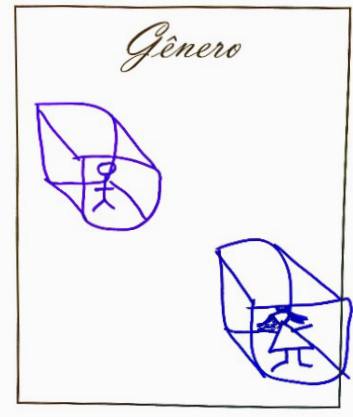

Note: Gênero - Gender

Source: Transwoman 17, Costa Rica, 2015.
Figure 3 - Free drawing technique: sex associated with words "boxes" and "labels"

\section{Gender associated with the words "behavior" and "must be social"'}

And in this way these differences between men and women were fed by my family and teachers [...] I remember this very strongly in my mother. Very strong indeed, as she was really strict about this, in this matter of me behaving like a boy [...] She, because of what the neighbors were talking about, tried to take over me [...] even the frustrations she had she placed them on me and tried to dominate me with her ideas [...] And there it is! I have suffered a lot from this [...] at the June festivals, which is something folkloric, you know, that every school has, in every country we celebrate it [...] I remember that I never wanted to dress like a country boy, dress as a boy, make a little mustache, make sideburns. I wanted to put on a lacy dress and dance in that group of girls with a male partner, so I always hoped that the group of boys would be full so I could dress up as a girl, but that never happened. (Transwoman 15, Brazil, 2014)

I started to realize I was different since I was born [...] I always knew I was a woman [...] because of the toys mainly, because I knew what it was boy toy or girl toy, I played with girl toy and boys played with boy toy, I always wanted to be the mother in the games, and the boys did not want to be [...]. (Transwoman 7, Brazil, 2014)
When I decided to come out as a woman, I was 15 years old and I told [my family] I didn't want to study anymore, because I was being terribly bullied at school and I didn't deserve that [...] Back then my father stopped talking to me and he made all my family do the same [...] I remember that he used to hit me so hard that "I've lost conscience" [sentence meaning she was almost unconscious], because he believed that I could go back being a man after being beaten up [...] and he always said to me: "You need to be beaten hard to become a real man with hair on his chest." (Transwoman 14, Costa Rica, 2015)

We add that some statements have evidenced the effective representation of gender associated with the sociocultural construction. Moreover, some participants, while exploring their memories and telling their life histories, recalled the strategies used by different institutions to implement these ideologies.

\section{Gender associated with the word "culture"}

My entire life has been oppressed, at first because I felt that I liked what girls liked, and culturally, you cannot do it. But I did not show it to everybody like that, because, let's say that, according to my culture, it was not normal, like, I could not ask my mother, "I want a doll!". She would gave me a cart, but on vacation, I always went to my girl cousins' house, all of them about the same age as me. (Transwoman 13, Brazil, 2014)

[...] For me, this crap is a cultural thing, for instance, you know that here in Tiquicia there are rules for everything [...] people believe in them and this makes us obey whatever our great grandparents tell us to do. (Transwoman 10, Costa Rica, 2015).

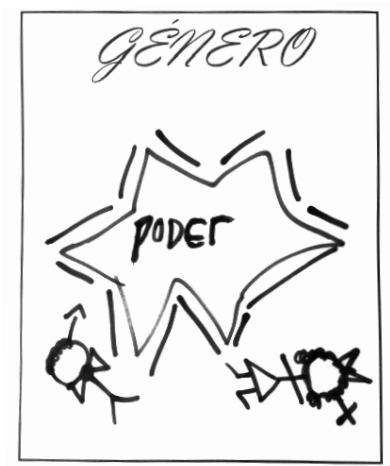

Note: Gênero -Gender; Poder-Power Source: Transwoman 27, Costa Rica, 2015.

Figure 4 - Free drawing technique: gender associated with power

Taking this into consideration, it is clear that gender presented itself as an institution of power and political-cultural domination capable of leading the bodies to standardized behaviors, not allowing (or preventing) the plurality or diversity of manifestations of the ontological being itself.

For this concept, the central nucleus consisted of the words "power and norm" (being normal/normativity). Furthermore, the social representations of gender linked to power, domination and normatization were anchored in some experiences of physical and psychological punishment during childhood and adolescence by the relatives (father, mother, siblings, uncles 
and aunts) and other social actors such as teachers and spiritual leaders. Hence, it is evident in gender representation that it is a regulatory ideal associated with power and domination which, for the participants, did not inform how men or women are like, but how they should be, act, think and behave.

Converging to this idea and starting from the analysis of content undertaken, the concepts of sex and gender, in the different realities, seem to be linked to the understanding of being procedural technologies that allow to hierarchize or to categorize the human beings in two totally opposing, antagonistic, and even irreconcilably different, poles.

Particularly, one of the points to be emphasized refers to the initial ability of sex to define genders and, similarly, to the inexorable and relentless ability of gender to (re)create new sexes in trans identities.

Finally, we emphasize that performing the global representational analysis of the concepts of sex and gender in the two realities studied was only possible because the respective processes of social exclusion, stigmatization and discrimination were significantly similar in both contexts.

They are realities reiterated by the reports of survival and struggle against patriarchal and necropolitical discourses that insist on reinforcing the invisibility of unintelligible identities that escape this current hegemonic cisgender standard.

\section{DISCUSSION}

Structural representations of sex and gender undergo transformations linked to the various vital circumstances that produce particular subjective experiences and to the conceptions that the subject has of both his/her cultural context and the world. Thus, it is possible to observe that sex-gender differentiation constitutes a preeminent phenomenon of symbolic life and social cognition within our community, capable of illustrating the necropower that these linguistic categories have to determine what we know about the world.

This categorical dimorphism, on one hand, introduces the taxonomic categories male/female, masculine/feminine, and, on the other, exposes the (seemingly) undeniable fact of its universality (not of content). Based on these epistemological anchorages, and in the face of human diversity, these generic and sexual representations emerge as a classificatory concept.

Therefore, it is important to point out that, in the construction of the representations of the participants of this research, both the relationship - in which underlies the (self)recognition that the person establishes with other members of the social-political cloister - and the relation that his/her group has with the structural instances of bio/necropower and knowledge, have interfered.

By logical extension, these social representations (sometimes complex or ambiguous) face tensions that generate contradictions and manifest themselves in a paradoxical way. The daily life experienced by the participants explains the gap between ideality and reality, making sexual and generic prescriptions, with their implicit assumptions, remain valid.

At this point, the division between sex and gender seems to continue to prolong the opposition between the supposedly natural and the supposedly cultural (and, according to what was elucidated in the research, there seems to be some technological artificiality in sex and naturalness in gender) ${ }^{(9-11)}$.

This dichotomy would not be a problem if it did not perpetuate the underlying opposition: the biological as a transforming (annulling or even destructive) entity of an apparent social order. In this sense, it is valid to analyze in more detail the division between sex and gender, because a careful look shows that discourses continue to prolong the opposition between masculine and feminine as essentially antagonistic entities ${ }^{(11-13)}$.

On the basis of the vast experience gained in fieldwork, we allow ourselves to criticize this dichotomy between the natural and the artificial (cultural), since we consider that the distinction between nature and culture widens the separation of inborn and acquired, and the subjective manifestations showed that these assertions (or statements) transcend the supposedly natural as a transformer of a social order and of the social as the transforming entity of a supposed natural order.

Accordingly, the patriarchal bias evidenced here is undeniable, since analyzing the transformations undergone by the eruption of sex-gender institutions in the sociolinguistic field, we find that these concepts and their consequent ideas of femininity and masculinity suffered, in the early 1900s, a regrettable fetishization, as the origins of this naturalization and its possible consequences were never considered ${ }^{(14)}$.

This fetishization led to the eventual naturalization of sex as irremediably attributed by the biological field and of gender just as a cultural institution obligatorily accepted. The separation of sex and gender then ceased to be a concept of support that protected irreconcilable differences and allowed openness to new research, imposing itself as an obstacle due to the complexity of its universal intelligibility.

Thus, sex and gender remain, still currently, irremediably bound in classificatory discourse, despite efforts to separate their importance in each society. Therefore, we postulate, based on the thinking of Scott (1986) and Stolcke (2012), that the condition of being transwoman or transman would be linked to a pervasive logic that dominates and consolidates the individual psyche and allows others to classify people in groups according to their sexual (in)consonance ${ }^{(15-16)}$.

In spite of this, trans-identity can be understood as a process that begins at the individual level and is constructed in an (in) voluntary way, while at the same time it is regulated by supraindividual, cultural, historical, permanent and almost unmodifiable patterns. We could then articulate it with social practices, with the idiosyncrasy of each region and with the values that, once acquired and assimilated by the individual, seem to be irrevocable.

Considering the complexity that generates the definition and total representation of the connotations of gender and sex, we find, as a valid possibility, to approach the assumptions declared by Judith Butler (2006), consonant with Scott's (1986) proposal, but which, with a more radical style, challenge the categories of sex, gender and identity, by trying to separate, polarize and (over)determine the subjects ${ }^{(15,17)}$. Thus, we return to its concept of performativity and its impact on the constitution of the subject (although Judith Butler was strongly criticized for taking this concept and restructuring it with the support of philosophers such as Althusser and Derrida). 
At this point, Butler ${ }^{(17-18)}$ proposes that the individual's identity, as well as gender and sex, is nothing more than a permanent cognitive performance, that is, a set of previous diverse and extraneous norms and actions of oneself, repeated constantly.

At the same time, we agree with Althusser ${ }^{(19)}$, in the assertion that the individual is free and responsible for his/her acts, but he/she is subject to an ideology that acts as a superior authority and thus deprives him/her of all freedom, except to accept his/her (irremediable) submission. It is evident, therefore, that the individuals are supportive of the structural relations in which they are situated, that is, the subject acts to the same extent in which he/she suffers the action of the system ${ }^{(20-21)}$.

The echoes of this political proposal - made visible in the statements - refer to discursive subversion by means, no longer of violent resistance, but of permanent transgression of social structures. Further advancing, as far as the (bipolar and classificatory) discourse of our society is concerned, the permanent repetition of discursive and practical rites that certify masculinity or femininity, based on a supposedly "natural" genitalia, which allow the intellection (understanding) of man or woman, requires the systematic exclusion of desires, attractions, performances and practices that escape the cisnormativity and intelligibility of the genders.

Specifically, having an identity that converses linearly with sex and gender means hearing an order that comes from nowhere but is heard everywhere. Returning to an aforementioned idea, the present society makes it necessary to validate the imposition of a cisnormative posture by (veiled or explicit) rejection of the forms represented by the trans spectrum.

In this sense, the only exhortation we undertake is to consider the possibility of intervening in this status quo, which is the social device of bio/necropower, control and domination - and at the same time challenging the source of the subjects' conflicts (hegemonic discourse), which could become the engine of a significant change.

In the experiences reported in the life histories of the trans participants, before elaborating the social representations, it was evident that society considers them abject beings, not because of the supposed cognitive dissonance they make of femininity/masculinity, but because of their corporeal and proxemic discourse, which proves/d to challenge the established parameters, so often repeated, then naturalized.

We also point out that the diversity of representations (hostages of the opposition/polarity of the binary logic of stereotypes that will produce exclusive models of behavior) is reduced to a construction defined by dualisms: masculine/feminine, activity/ passivity, assertiveness/expressivity, equality/inequality, reason/ emotion-passion, which, by masking the heterogeneity of the behavioral categories and their asymmetry, compel the subjects, leading them to the overdevelopment of skills and attitudes considered adequate to their sex, ethnicity and/or class ${ }^{(16,22)}$.

Thus, based on previous concepts, we articulate sex-gender representations as the inexorable result of an evolutionary process by which the expectations and behavioral/social norms relative to the dimorphism are internalized, and that refer to the psychological sense of the individual being a man or woman with the social and psychological behaviors that society designates as masculine or feminine. This same perception was apprehended already in the interviewees' infancy and had a significant value in the social (in)adaptation by influence of both maternal and paternal models and the social roles of close adults that imposed their cisheteropunitive marks on them.

It is necessary to recognize that even when all the concepts related to the difference between the sexes and the genders maintain a strong interrelationship, they do not allow to establish fixed inferences, since sex is not an essence (as shown by transsexuality itself), but a techno/biologically imposed contingency, and gender is not a static energy, but a socially built technology (with a pinch of nature).

As pointed out earlier, to assert that sex is a techno/biologically imposed category may seem contradictory and even unsustainable, since a definition of sex that ignores the opposition traditionally made between nature and biology may seem incoherent. However, we resort to Preciado's principles ${ }^{(12)}$, which consider technology and sex as strategic categories within the current anthropological discourse framework, in which the category "man" has been artificially developed by virtue of its affinity with technological apparatus, while the category "woman" has been described plastically due to the apparent passive sexual availability.

Specifically, having appealed to the notion of the techno/ biological concept of genitalia, whose scope increases significantly, we could introduce in this discussion the concept of contrassexuality delimited by Paul B. Preciado ${ }^{(22)}$, who tries to question the debate between essentialism and constructivism of the sexes and advocates juxtaposing both paradigms.

At the same time, the author mixes the constructivist positions which argue that the categories of man and woman are not natural, being, in his view, culturally accepted normative ideas, constructed and subject to changes in time and cultures, and the essentialist positions that sustain that the genitalia find a refuge in biological models according to which the difference between sex and gender depends on physical and psychic structures and (in)variables that prevail far beyond cultural and historical differences.

To conclude, under this paradigmatic logic, we clearly observe in the worked representations that trans identity is a technology, and we consider that the different binary (and illogically antagonistic) elements in the dialectic of the sexgender system, denominated man/woman, male/female, are nothing but machines, products, elements, instruments, tricks, prosthetics, networks, applications, memes, avatars, artificially created energy flows, mechanical keys, laws of behavior and circulation, boundaries and constraints, which work within a specific necropolitical and social framework.

\section{Limitations of the study}

In general, the main aim of this study was fulfilled, since we assume it to be a pioneering work. However, it seems pertinent to mention some limitations that may be addressed in future research. The main ones were related to the sample circumscribed only to two countries and to the difficulty of locating transmen in a similar proportion to transwomen. Likewise, this being a cross-cutting reality in several areas, it seems 
pertinent to carry out studies of a multidisciplinary and multifactorial nature in collaboration with other professionals who have privileged contact with this population.

\section{Contributions to the area of nursing, health or public policy}

The understanding of the social representations of sex and gender that permeate the common sense of self-identified people within the trans spectrum demonstrates the importance of lay knowledge for contemporary societies and, more specifically, for health professionals.

In fact, this understanding helps to destabilize and de-stigmatize the hegemonic cisheteropatriarchal thinking, which draws the boundaries of intelligible vs. unintelligible, of abject x "normal," in order to offer a politicized, integral, humanized and universal care to all those who so require.

\section{FINAL CONSIDERATIONS}

In this article we sought to reflect, analyze and understand the different representations that trans people express through their knowledge and actions regarding sex-gender technologies, dilemmas and paradoxes (and how these aspects operate in the subjectivity of these subjects) in the current technonormalizing society.

The transit through so many places and knowledge makes us realize the lines of force and tensions present in the discussion of trans identities and their subjectivities. We perceive that the theme is inexhaustible, that there are no absolute solutions or definitions, nor unequivocal truths regarding the discursive and representative construction of sex and gender.

It became clear in the representations that gender and sex are now (politically and artificially) constructed individually and collectively, over time, based on multiple influences and assuming some self-determination. The trans being develops his/her own representations through the messages culturally sent to him/her by his/her context so that he/she compulsorily accepts them.
Despite the relatively significant advances in recognition and rights for trans people, there is still no reflective analysis of the philosophical problem that underlies identity and that originates from the sex-gender difference, even less when in the discourse there are multiple polysemous presuppositions, for example, the apparent normality or naturalness of only two sexual and gender possibilities - a fact evidenced in the two realities investigated.

In this direction, gender and sex are social constructions that allow people to play a role in society that defines places based on bio/necropower positions. Gender and sex are not static (and definitive) spaces of resistance, but monuments that are constantly being built. In addition, both structures have the capability of modeling through non-procedural/linear identification. In this logic, gender - and gender identity - has the ability to shape new sexes and, at the same time, sex has the ability to (re)create new genders.

Cumulatively, gender and sex are (pre-)formed identities that are characterized by obliging repetitive (and continuous) actions with the intention of shaping the bodies according to a certain social norm. In this study, both seem to disguise themselves as categories that have biological and social traits used to institutionalize a regulated language, based on a genital plasticity.

The possible reconstruction of sex-gender binarism would mean the total pluralization and flexibilization of these identities, outside static and rigid paradigms. We emphasize that the plurality of discourses represented here is the most significant point of an active semantic struggle between the dominated and the dominant, in a necropolitical view, facing the normalizing and regulating values that have prevailed since the beginning of the 19th century. In addition, we consider that the productions of the sex/gender system, as well as the institutions that permeate or determine their meaning, must be redone and reinterpreted.

Finally, we do not consider that it is about simply (re)producing a prostituted and little-established discourse to undo the gender from situations, moments, beings and spaces, but rather to modify the positions of enunciation based on the place of each social protagonist.

\section{REFERENCES}

1. Warner M. The trouble with Normal: sex, politics, and ethics of queer life. New York: Free Press; 1999.

2. Lucal B. What it means to be gendered me: life on the boundaries of a dichotomous gender system. Gender Soc[Internet]. 2014 [cited 2016 Mar 30];13(1):781-97. Available from: http://www.li.suu.edu/library/circulation/Gurung/soc2370sgWhatltMeansToBeGenderedMeFall11

3. Laqueur T. Making Sex: Body and Gender from the Greeks to Freud. Cambridge: Harvard University Press; 1994.

4. Knudsen PPS. Gênero, psicanálise e Judith Butler: do transexualismo à política. [Tese] São Paulo: Universidade de São Paulo. Instituto de Psicologia; 2014.

5. Harrison L. Gender relations and the production of difference in school-based sexuality and HIV/AIDS education in Australia. Gender Educ. 2000;12(5):19-25.

6. Iglesias A. Dos cuerpos, un alma. Buenos Aires: De los Cuatro Vientos; 2011.

7. Moscovici S, Vignaux G. The Themata concept. In Guimelli C. (Ed.), Structures et Transformations des Représentations Sociales. Neuchâtel: Delachauxet Niestlé; 1994.

8. Bardin L. Análise de conteúdo. 3a ed. São Paulo: Edições 70; 2011.

9. Lamus D. Raza y etnia, sexo y género: el significado de la diferencia y el poder. Reflex Pol[Internet]. 2012 [cited 2016 Mar 30];14(27):68-84. Available from http://www.bdigital.unal.edu.co/39766/1/Race\%20and\%20ethnicity.pdf

10. Missé M, Coll-planas G (Eds.). El Género desordenado: críticas en torno a la patologización de la transexualidad. Barcelona: 
Editorial Egales; 2010.

11. Preciado PB. Manifiesto contra-sexual: prácticas subversivas de identidad sexual. Madrid: Pensamiento Opera Prima; 2012.

12. Rubin G. Thinking sex: notes for a radical theory of the politics of sexuality. In Abelove H, Barale MA, Halperin DM (Eds.). The lesbian and gay studies reader. New York, NY: Routledge; 2013.

13. Shields SA. Gender: an intersectionality perspective. Sex Roles. 2013; 59: 301-11. Available from http://dx.doi.org/10.1007/ s11199-008-9501-8

14. Scott J. Gender: A useful category for historical analysis. Am Hist Rev. 1986; 91:1053-1075.

15. Stolcke V. ¿Es el sexo para el género como la raza para la etnicidad? Mientras Tanto[Internet]. 2012[cited 2016 Mar 30];48:87-111. Available from: https://disciplinas.stoa.usp.br/pluginfile.php/269230/mod_resource/content/0/Verena\%20Stolcke.pdf.

16. Butler J. Precarious life: the powers of mourning and violence. London. New York: Verso; 2004.

17. Butler J. Undoing Gender. New York. London: Routledge; 2014.

18. Althusser L. Aparelhos Ideológicos de Estado. $3^{\text {a }}$ edição. Rio de Janeiro: Edições Graal; 2003.

19. Ferré JV. ¿Corregir el cuerpo o cambiar el sistema? la transexualidad ante el orden de género. Sociol[Internet]. 2013 [cited 2016 Mar 30];24(69):61-78. http://biblioteca.ues.edu.sv/revistas/10702483-4.pdf

20. Fausto-Sterling A. Sexing the Body: gender, politics, and the construction of sexuality. New York: Basic Books; 2013.

21. Looy H, Bouma $\mathrm{H}$. The nature of gender: gender identity in persons who are intersexed or transgendered. J Psychol Theol. 2015; 33:166-78.

22. Preciado PB. Testo Yonqui. Madrid: Editora Espasa Calpe; 2008. 